\title{
Research on the integration of university party building project into college students' Ideological and political education in the micro Era
}

\author{
Fei Sun ${ }^{1}$, Haoming Lai ${ }^{2}$ and Li Guo ${ }^{3}$ \\ 1,2,3Nanchang Normal College, Nanchang,JiangXi,330103, China
}

Keywords: the micro era,Party Building in Universities,Ideological and Political Education.

\begin{abstract}
Internet as the carrier of the micro era inevitably produce some transformative effect on the behavior of the ideological and political education of college students.It is of great significance for the healthy growth and development of contemporary college students to carry out the party and League construction under the micro era, to innovate college ideological and political education work, and find out from the need to overcome the predicament college party building in the micro era starting to try to strengthening and improving the caucus analysis and path construction of university ideological and political education in the micro era. The paper tries to analyze the approach to strengthening and improving party construction and the ideological and political education in colleges under the micro era aiming to break the dilemma of the party construction in colleges and universities.
\end{abstract}

How to rely on the university party organization construction, strengthen the ideological and political education work, how to carry out the party construction under the micro era, how to innovate colleges and universities ideological and political education work have become increasingly an important research focus for education workers, which if of great significance for the healthy growth and development of contemporary college students.

This study is mainly carried out in China, with more and more domestic scholars are studying the process of transformation from the traditional to the micro era, in which the traditional mode was not completely broken. Although some scholars have strengthened research on Promoting College Students' Ideological and political education of the party building under the micro era, the research is still relatively fragmented; Domestic scholars have started from the party construction and ideological and political education in Colleges and universities, some carry out the construction of the party and the Youth League from the use of new media, few combine the two and put it in the context of the micro era to carry on the elaboration. In recent years, the domestic academic research on this issue, mainly from the following aspects. 1, Research on party building in Colleges and universities under the micro era 2, study of college party construction and ideological and political education of college students 3, study of Ideological and political education of college students under the micro era 4, on the countermeasures for strengthening and improving college party building and ideological and political education for College students.

For this topic, the focus is on how to promote the ideological and political education of university students in a specific field. To meet the needs of social development, the issue of how to promote the ideological and political education of college students in the micro era, to provide specific research results. For the micro era of college party building into the ideological and Political Education Research of the general situation is as follows. 


\section{First of all, the research on the construction of college party under the micro era.}

Mainly from the main characteristics of the development of new media, the rational analysis of the new media to the ideological construction of the party's ideological construction of the opportunities and challenges, to explore the new media environment, the new ideas of the party's ideological construction. Through the example analysis the urgency and necessity of using new media to carry out the construction of grassroots party organization in Colleges and universities to take the building work, and is the primary organization of the caucus based on how the objective reality, through the systematic use of new media means, integration of the use of old and new media platform, strengthening connotation construction, etc., to carry out the construction of the party building work, the theoretical thinking and path exploration.

\section{The second is the study of Ideological and political education of College Students Party Construction and.}

From the significance of the study, that is why it is necessary to strengthen the Communist Party construction and ideological and political education of college students, the research purpose and significance is what research, analyses the research background. Some scholars have systematically analyzed the causes and Countermeasures of college party building and ideological and political education in Colleges and universities.

\section{Finally, some countermeasures to strengthen and improve the party construction and the ideological and political education of College students.}

For the countermeasures to strengthen and improve the strategy of the Communist Party construction and ideological and political education of college students, he thinks to to the 18 great mind as guidance, adhere to the scientific concept of development, continue to study new approaches to take new measures, the scientific and realistic attitude and the spirit of reform and innovation combined, and comprehensively promote the party construction and ideological and political education of college students. From the micro and macro two dimensions of thinking and analysis, in the new situation, further analysis of the impact of new media on college students, explore new media environment to improve the effectiveness of Ideological and political education in the new way.

\section{One,the significance of using college party building to promote the ideological and political education of college students in the micro era}

Through the research of this problem can enrich and perfect the modern ideological and political education discipline category system construction, can improve the ideological and political education of college students of the pertinence and effectiveness. It is ideological and political education to keep pace with the times and adapt to the objective requirement of the micro era, the development of information networks, it can better more convenient to realize the objectives of Ideological and political education, and can make the boring theory becomes more and more vividly. It is also beneficial to developing students' learning potential and cultivate students' research, autonomous learning ability, to strengthen and improve the party members of college students network content construction, sing the main melody of the network, improve network ideological and political education theory system. 


\section{Two, the micro era of college party building needs to break through the dilemma}

In order to further strengthen the party building and ideological and political education in the direction of the. Eighteen report of the 2012 meeting of the party put forward clearly: "to strengthen and improve the construction of Internet content, sing the main theme online. Strengthen the management of the network society, and promote the orderly operation of the network. " Thus, for the study of the micro era of the value and significance of the Communist Party construction and ideological and political education of college students study is particularly important.

First, the youth university student's thought and the behavior guide way waits for the further excavation. The traditional mode of education can not meet the diverse needs of young college students. The full use of the new media can make up for this deficiency.

Second, the ideological and political education of young college students is not very good with the party building of College students. Although some grassroots organizations will build some education sites such as red sites, but due to the maintenance and update does not lead to a positive interaction with young students to participate in the initiative to reduce. Education form also has the traditional, the education position is small, the function is not perfect, the education content is unitary, the education process is the former tight loose, the heavy development light education, the quantity, the light quality phenomenon has occurred.

Third, college students' Ideological and political education effectiveness innovation needs to be strengthened. Innovation is an important way for the development of young college students, the party organization in Colleges and universities should through innovative education mode, method, content, to guide young students to better participate in and strengthen college students' Ideological and political education to adapt the new situation.

\section{The path of strengthening and improving the party building and ideological and political education of College Students under the age of three, new media.}

The acquisition of information in the micro era is easier and more complex. The diversity of contemporary college students' ideology reflects the diversity of the needs of the young students, which brings new pressure to the ideological and political education work. During this period if the student Party member's exemplary vanguard role is not obvious, the students to participate in the enthusiasm is not high, will be the development of college students extremely unfavorable, so one of the path is to give full play to the party members' model leading role, the group learning activities led the broad masses of young students, and thereby to promote the role of Ideological and political education of the students.

First of all, in the micro era, the role of the model should be fully played. To display the advanced deeds of outstanding undergraduate Party member in university campus of multiple platforms, such as in a school wide selection of "top ten campus of college student party members ", the college departments can also the outstanding Party members among college students as a typical set. Selection process the young college students can participate in the entire process, as by website published the advanced deeds, through the microblogging and launched voting to give full play to the role of multimedia, such as Nanchang normal college the student party members as Party members of college students typically set up to role model and leading role and guiding role. In the demonstration role of a party member is a banner, through this form of propaganda, propaganda advanced in young college students can set up a banner, so that their learning direction, to catch up with the target. Also a typical can also lead a large, because most of the people is can do to emulate, 
because the power of example is infinite, typical propaganda can also pool of young college students, transfer positive energy, to the spirit of the young college students fill "calcium".

Secondly, leading the new media, building information platform, full use of new media, take the initiative to occupy the network ideological and political education positions. Using new media to improve the party construction work pay special attention to the ideological and political education of the youth at the same time we must abandon the web 1.0 era "one-way transmission " stage, and is about to "two-way transmission or for the extensive use of interactive Web2.0 era of new media to college students ' Ideological and political education is particularly important, such as websites, Fetion platform, micro channel platform,S M S,MSN,QQ,microblogging and other new media tools to strengthen ties with the student and youth and broaden the channels. Such as Jiangxi Science University of technology opened ent network - - http : // www. jxustsrw . cn / portal.php. ${ }^{[1]}$ has become Jiang xi Province Colleges and universities ideological and political education demonstration network, Shuren network for mobile phone users, on its home page also provides micro QR code for mobile phone users easy access to sites that use this kind of website with condensed young students of the new media on College Students Ideological and political education to the very important role. Many colleges and universities set up the theme website of Ideological and political education, and actively make use of the various departments of the campus network, and the website of each department to serve the ideological and political education of the university. Network ideological and political education in Colleges and universities is the inevitable trend of the development of Ideological and political education in the era of information network. It is necessary to further strengthen and improve the ideological and political education of students. ${ }^{[2]}$

Last so the second path is to make full use of new media, the caucus network platform construction, realize the line, line learning linkage, promote college students' Ideological and political education. Such as Internet sites, WeChat classroom, the opening of the $\mathrm{Mu}$ class, etc. Such as in the ideological education of college students, the new media way open ideological and political network interactive platform, such as " China Education " in 2016 January 08, published by Hebei University of economics and business to build the college students' Ideological and political education network platform, Hebei University of economics and business early in 2016 perfect "look up at the starry sky " website, and an additional the counselors ' blog log ", " career planning", " employment ", " QQ connection "multiple columns and assign someone on the network on duty by turns, at any time to answer students put in line. Today,"look up at the sky," the website of the blog total visits exceeded 50 thousand times, the maximum number of visits to more than 700 people, more than 300 students to leave a message and comments, answer questions more than 200 . ${ }^{[3]}$ Also, such as GanNan Normal University, the teacher opened the WeChat classroom is a student interaction with the network classroom, the use of such a kind of and students online, offline exchange of learning linkage mode, very popular with students. The party's organization construction by means of micro channel, micro blog, network and other ways to physical classroom into air classroom "schools,departments,grade and class of Party organizations ideological and political education " new media ", try to be familiar with the contemporary young students life, work, learning, entertainment and the way of reading, with the help of the power of new media, make themselves into all kinds of young, in-depth observation and meticulous research, the building of grassroots organizations the most vivid, the most vivid materials. scholars Liu Cangshan in the college party construction and college students' Ideological and political education research "referred to the strengthening and improving strategy of the Communist Party construction and ideological and political education of college students of fourteen respects, systematic answer how to strengthen college party construction and ideological and political education of College Students 
work, he thinks to take the spirit of the $17^{\text {th }} \mathrm{C} \mathrm{P} \mathrm{C} \mathrm{National} \mathrm{Congress} \mathrm{as} \mathrm{a} \mathrm{guide,} \mathrm{adhere} \mathrm{to} \mathrm{the}$ scientific concept of development, continue to study new approaches to take new measures, the scientific and realistic attitude and the spirit of reform and innovation combined,and comprehensively promote the party construction and ideological and political education of Students. Anyway, in the era of new media using party to promote the ideological and political education of college students in the traditional classroom, blackboard newspaper publicity, the party newspaper publicity to strengthen the social practice of college students and volunteer service activities and actively carry out rich and colorful cultural activities on campus, Party member education activities, make full use of the Internet as the core of the new media, the scientific path to play the role of the party building in Colleges and universities, to raise the overall level of College Students' Ideological and political education, strive to young students to become the cause of socialism with Chinese characteristics qualified builders and reliable successors.

\section{The overall objectives of the study are as follows:}

1,Ideological and political education environment of college students in the era of media and its optimization. the use of new media to innovate the ideological and political education of Students 2, The influence of the students' Thoughts on the new media

3,To explore the key points and difficult points of strengthening and improving the path of Ideological and political education of university students under the micro era

The effectiveness, feasibility and operability of the path

4,In the use of new media and other means of mechanism, through the Communist Party construction work to promote the development of Ideological and political education in Colleges and universities, to find a better starting point .

2015 Jiangxi provincial university humanities and social sciences research project, project approval number: M K S 1552.

Study on the youth project of university party building in Jiangxi Province in 2015 College party construction and ideological and political education innovation in micro Era(JXGXDJKT.QN -201509)

\section{Reference:}

[1]"Jiangxi University of Science and Technology opened Shuren network " --http :/ / www .jxustsrw . cn / portal .php ( 201014$)$

[2] Yan Shifeng Zhou Hongsong,"Hebei University of Economics and Business to build a network platform for ideological and political education of college students "[J]. China Education News [3]Liu Cangshan the study of college party construction and the ideological and political

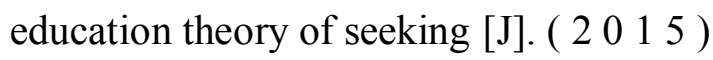

